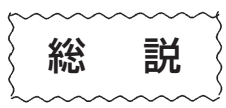

\title{
レッドマウス病
}

\author{
坂井貴光*
}

（2021年 1 月 5 日受付）

\section{Redmouth Disease}

\author{
Takamitsu Sakai* \\ Fisheries Technology Institute, National Research and Development Agency, \\ Japan Fisheries Research and Education Agency, \\ Nagasaki 851-2213, Japan
}

(Received January 5, 2021)

\begin{abstract}
Redmouth disease is caused by the infection of the enteric bacterium Yersinia ruckeri. The disease was first noticed in rainbow trout Oncorhynchus mykiss in the USA in 1950s and has since been observed in salmonids and some other fishes in many countries. Y. ruckeri can be classified into different biotypes, serotypes, or genotypes, according to biological properties such as motility or enzyme activity, antigenicity, or gene sequences. In particular, O-antigen, which is one of the markers for serotyping, is an important antigen for the vaccination for of $Y$. ruckeri. In Japan, redmouth disease is listed as one of the notifiable diseases of aquatic animals by the government to prevent occurrences or spreading of the disease. This review describes topics necessary important for the diagnosis and control of the disease.
\end{abstract}

Key words: Yersinia ruckeri, redmouth disease

レッドマウス病は, Yersinia ruckeri を原因とする細菌 感染症である。本病名は，1950年代にアメリカ合衆国で 発生したニジマスの口周辺の発赤を伴う細菌感染症に由 来する（Rucker, 1966)。近年では, 多くの国々で発生す るようになり, ニジマス以外のサケ科魚類やその他の魚 種でもY.ruckeriの感染による被害が確認されている。以 下，原因菌 Y. ruckeri 及び本病の特徵について解説する。

\section{原因菌の性状}

Y. ruckeri は, 腸内細菌科に属するグラム陰性短桿菌で ある。菌体のサイズは, 直径 0.5 0.75 $\mu \mathrm{m} \times$ 長さ $1 \sim 6$ $\mu \mathrm{m}$ であり, 菌株によって菌体の長さが異なる (Austin et al., 1982)。基準株（Type strain）は，アメリカ合衆国ア イダホ州でニジマスから分離された CDC2396-61株であ り (Ewing et al., 1978), American Type Culture Collec-

\footnotetext{
水産研究・教育機構水産技術研究所

* Corresponding author

E-mail: tasakai@affrc.go.jp
}

tion（ATCC）には ATCC29473として, National Collection of Industrial Food and Marine Bacteria (NCIMB) に はNCIMB2194として寄託登録されている。本菌のゲノ ムは全長 3.7〜3.8 Mbp の環状二本鎖 DNA で (Kumer et al., 2015), G + C 含量は47.5 48.5\%であり, 他のエル シニア属細菌と同様の含量である (Austin et al., 1982)。 本菌は, トリプチケースソイ寒天培地, 普通寒天培地, コロンビア血液寒天培地, マッコンキー寒天培地やサ ルモネラシゲラ寒天培地上で発育し, 至適増殖温度は $22^{\circ} \mathrm{C} \sim 25^{\circ} \mathrm{C}$ である（Ross et al., 1966; Wrobel et al., 2019）。 トリプチケースソイ寒天培地では， 2～3 日以内にコロ ニー (乳白色, 半透明, 表面や辺縁は平滑) が見られる (Fig. 1)。Yersinia 属細菌の選択培地として知られる CIN 寒天培地では発育しない（坂井ら， 2006）。Y.ruckeriの 選択・鑑別培地として, Shotts-Waltman 寒天培地 (SW 培地）とROD 寒天培地が報告されている。但し，これ らの培地では Vibrio anguillarum 等の Y. ruckeri 以外の魚 病細菌も発育する可能性がある。加えて, 鑑別の指標と 
なるコロニー及びその周辺の変化が見られない菌株があ り, Y. ruckeri の種同定では他の検查法も併用した方が良 い。生化学的性状試験で示す特徵的な性状については, $\beta$ - ガラクトシダーゼ試験及びオルニチンデカルボキシ ラーゼ試験で陽性を示し, ウレアーゼ, 硫化水素及びイ ンドールの産生は見られない。糖分解については, D- マ ンニトール及びマルトースが陽性，イノシトール，L- ラ ムノース，サッカロース，D-メリビオース，D-アミグ ダリンやL-アラビノースが陰性である (Ewing et al., 1978）。これらの性状は, 生化学的性状反応に基づく迅 速・簡易同定キットによる本菌の同定にも有用である。

1950年代から近年まで多くの菌株が分離されており, その型別として，運動性及びホスホリパーゼの産生の有 無に基づくバイオタイプ, 血清型, 複数のハウスキーピ ング遺伝子やパルスフィールド電気泳動法による遺伝子 型が調べられている（Tobback et al., 2007）。バイオタイ プについては，運動性及びホスホリパーゼ活性の両性状 を有するタイプ（バイオタイプ1）とこれらの性状を示 さないタイプ (バイオタイプ2) がある。バイオタイプ 2 では, 鞭毛の形成に関わる遺伝子に変異或いは欠損 が生じており，運動性に関わる鞭毛が形成されない (Welch et al., 2011)。血清型については，主にLPS の O 抗原に基づく型別が行われている。当初, 血清型は 1 種 類と考えられていたが，他の血清型も見つかり（Bullock et al., 1978)， 5 種類の血清型（O-1， O-2， O-5， O-6, O-7）が提唱された（Davies, 1990）。その後, 新たな血 清型（O-8）の Y.ruckeri がスコットランドのアトラン ティックサーモンから分離されている。 O-1 及び O-2 に ついては，それぞれサブタイプ（O-1a，O-1b，O-2a， O-2b，O-2c）が報告されている（Romalde et al., 1993）。 その報告の中で O-3 と O-4 が提唱されているが，これら

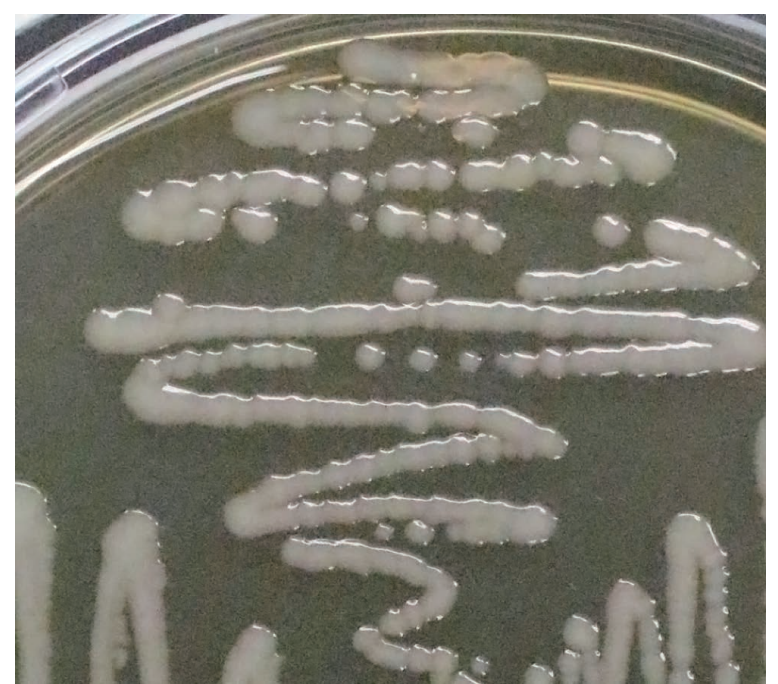

Fig. 1. トリプチケースソイ寒天培地上の Yersinia ruckeri のコ ロニー
は Davies（1990）の提唱における O-5 と O-6 に該当す る。O抗原は, 血清による本菌の殺菌において, 補体活 性化の古典経路に関与する抗原と考えられており（Haig et al., 2011), 不活化菌体ワクチンの重要な抗原と一つと 言える。当初, 血清型 O1・バイオタイプ 1 による被害 の報告が多かったが，その後，血清型 O1・バイオタイ プ2による被害が報告されるようになった（Davies and Frerichs, 1989; Austin et al., 2003)。近年スコットランド では, アトランティックサーモンの罹病魚から血清型 O-8のY.ruckeri が分離される頻度が高くなってきてい る。遺伝子による型別については, 複数のハウスキーピ ング遺伝子を用いたタイピングである MLST 法（Multilocus sequence typing 法）のデータが充実しており，そ のデータベースが Web で公開されている (PubMLST, https://pubmlst.org/)。MLST 法に基づく系統解析によっ て，これまで世界各地で分離されている菌株間の遺伝的 関係が分かっている（Bastardo et al., 2015）。

\section{症状および感染経路}

殆どのサケ科魚類がレッドマウス病に感受性を有する と考えられているが (Furones et al., 1993)，その感受性 の程度は魚種によって異なる。国内のアマゴ，ヤマメ及 びイワナについては, 感染試験でニジマスと同様の症状 を呈し（Fig. 2 and 3)，本病に感受性を示すが，各魚種 の累積死亡率はニジマスより低い（Sakai et al., 2012）。
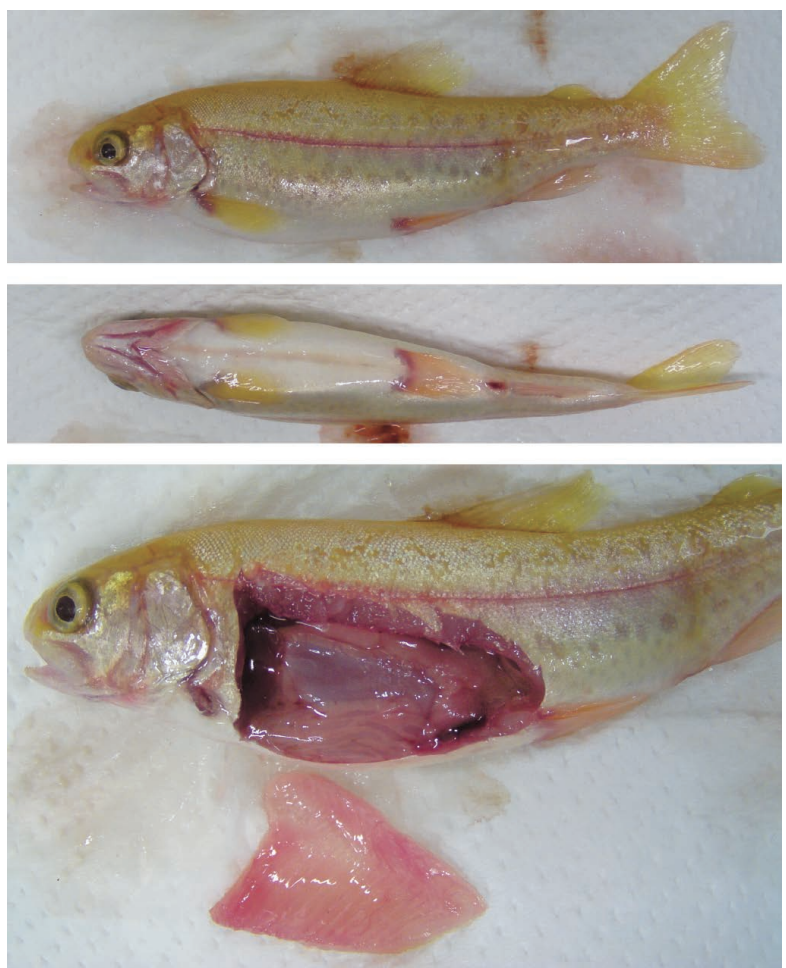

Fig. 2. Y. ruckeri の感染試験で見られたニジマス（アルビノ） の死亡魚 

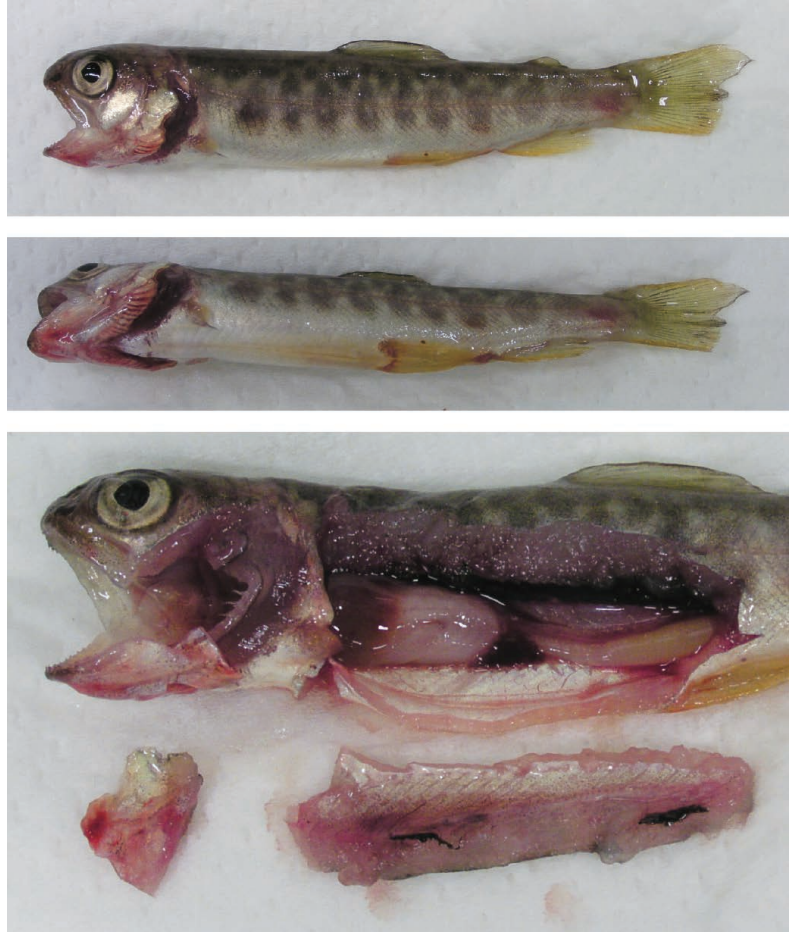

Fig. 3. Y. ruckeri の感染試験で見られたイワナの死亡魚

尚，国内では，アマゴ，ヤマメ及びイワナにおける本病 の発生例は無い。ニジマス罹病魚では, 体色黒化が見ら れ，口吻部，口腔内，下顎及び鰭基部が赤変（皮下出血） する（Furones et al., 1993）。剖検所見としては, 脾臓の 腫大が認められる他，肝臓，脂肪組織，腸管膜，腸後部 等に出血が見られる場合がある。また，胃腸管後部又は 排泄物に黄色粘液物が観察されることがある。病状の経 過は, 急性型, 亜急性型と慢性型に分けられる。急性型 の場合は, 春から夏にかけての水温上昇期に当歳魚で主 に発生し，30～60日間で累積死亡率は50～70\%に達す る。亜急性型は, 秋から冬にかけての水温下降期に流行 し，死亡率は急性型より低いものの，2～6 ケ月で10～ $50 \%$ に達する。慢性型は，死亡率は約 $10 \%$ と低いが，出 荷サイズの魚や親魚で発生しやすい点が問題になる。

魚体への Y. ruckeri の侵入経路については，ニジマスに 対する感染試験で詳細に調べられており，鰓，消化管及 び側線が主な侵入門戸と考えられている (Tobback et al., 2009; Ohtani et al., 2014)。また, 血清型 O1・バイオタ イプ 2 の Y.ruckeriに抢いては, 鼻腔の嗅上皮から脳内に 侵入する可能性が示唆されている (Strøm et al., 2017)。 鰓では, Y. ruckeri の感作から約 1 時間以内に二次鰓弁組 織内で菌体が観察され，その後，鰓の血管内でも菌体が 見られるようになる。血管内に侵入したY.ruckeri は，血 流を介して, 腎臓, 脾臓や肝臓等の様々な器官へ感染を 拡げる。病理組織観察においては, 脾臟, 肝臓及び腎臓 に局所的な壊死が多数見られる。腎臟では，尿細管の変
性やメラノマクロファージの増加も観察されることがあ る。

親魚からの垂直感染に関しては, アメリカ合衆国コロ ンビア川沿いの孵化場で行われた調査において, マスノ スケの雌親魚の体腔液, 未授精卵, 発眼卵や仔魚からY. ruckeri が検出された報告があり，その可能性が示唆され ている (Glenn et al., 2015)。

Y. ruckeri の宿主範囲は広く, サケ科魚類以外の魚種に も感染する可能性がある。ナイルティラピア, コクレン, ハクレンやチョウザメ等 (Eissa et al., 2008; Shaow et al., 2014; Wrobel et al., 2019）での発症が報告されてお り, レッドマウス病の典型的な症状である口や顎周辺の 発赤が, ナイルティラピア，アムールチョウザメとシベ リアチョウザメの罹病魚で確認されている。また，コク レンやハクレンでは, 腹部, 鰭基部や眼球に発赤が見ら れる。

病勢には水温やハンドリング等が影響を及ぼす。ニジ

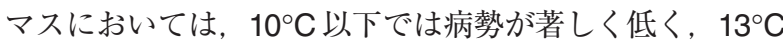
付近ではハンドリング等のストレスが発症の要因になり やすく, $18^{\circ} \mathrm{C}$ 以上では著しく病勢が強くなると考えられ ている。上述のナイルティラピアの発生時は, $16 \sim 24^{\circ} \mathrm{C}$ の水温上昇期であった。

\section{病原因子}

宿主の細胞や組織に影響を及ぼす菌体外産生物や宿主 内での生存に関わる III型分泌装置等が，本菌の病原因子 と考えられており (Wrobel et al., 2019), 菌体外産生物 質のプロテアーゼ Yrp1，ペプチダーゼYrpA 及び溶血素 YhIA については, 病原性との関連性が報告されている。 Yrp1 はセラリシン型のメタロプロテアーゼであり (Secades and Guijarr, 1999)，ABC トランスポーターか ら菌体外へ分泌される（Fernández et al., 2002）。Yrp1 の遺伝子が鰓や腸管の組織内で発現することに加え，本 遺伝子を変異株させた株がニジマスに対する病原性の低 下を示すことから（Fernandez et al., 2003）, Yrp1 は重 要な病原因子の一つとして考えられているが, Yrp1の遺 伝子を持たない病原性株もある。また，加熱処理で不活 化したYrp1を接種したニジマスは, 感染試験において 顕著な死亡率の低下が見られることから，感染防御抗原 の一つとして知られる。YrpA は，U32 ファミリーのペ プチダーゼである（Navais et al., 2014）。U32 ファミ リーのペプチダーゼは, Proteus mirbilis, Helicobacter pylori, Salmonella enterica や Aeromonas veronii におい ても, 感染に関与する因子と考えられている。Y.ruckeri でも，その久損株で病原性の低下が見られることから重 要な病原因子の一つと考えられている。溶血素 YhIA は, $5 \mathrm{~b}$ 型分泌装置から分泌される溶血素である。これらの産 生には $y h I A$ と $y h I B$ の 2 つ遺伝子が関わり, 各遺伝子 
はSerratia marcescens の 5b 型分泌装置の構成遺伝子に 相動性を示す (Fernández, 2007)。YhIA は, Y.ruckeriの 至適増殖温度より低い温度 $\left(18^{\circ} \mathrm{C}\right)$ で発現しやすく, 鉄 制限環境も発現の要因になる。各遺伝子の変異株には, 魚に対する病原性の低下及び魚類培養細胞に対する細胞 毒性の低下が見られることから，本菌の病原性に関わる 溶血素と考えられている。

\section{診断および防除対策}

本邦では，レッドマウス病は持続的養殖生産確保法に 指定されており，その診断は病勢鑑定指針に基づいて行 われる。臨床検査後の細菌検査において, チトクローム オキシダーゼ除性のグラム院性菌が分離された場合, Y. ruckeri に対するPCR 検査が分離菌に対して実施される。 発生時のまん延防止においては，施設，器具類や手指等 の消毒が重要である。本菌が30秒以内に死滅する有効塩 素濃度は $1.25 \mathrm{mg} / \mathrm{L}$ 以上であり, 有効ヨウ素濃度につい ては 4 mg/L 以上である（Yamasaki et al., 2017)。エ夕 ノールやイソプロパノールを有効成分とする消毒剤や逆 性石けん消毒剂も本菌に対する消毒効果が確認されてい る。

\section{残された課題}

本邦では，2015年 3 月にシロサケ梛化場でレッドマウ ス病が発生した。その後の発生は無いが, 今後も本菌の 国内侵入に対して注意が必要である。

国外のサケ科魚類養殖では，本病に対する市販ワクチ ンが使用されており，発生の予防に役立っている。一方， ワクチンの効果を適用できない新たな抗原型の Y. ruckeri 感染が発生する可能性は今後もあり，血清型等の抗原や 病原因子に関する研究は今後も必要である。防疫におい ても, 流行株に対する疫学情報の注視が引き続き重要で ある。

\section{文献}

Austin, B., M. Green and C. J. Rodgers (1982): Morphological diversity among strains of Yersinia ruckeri. Aquaculture, 27, 73-78.

Austin, D. A., P. A. W. Robertson and B. Austin (2003): Recovery of a new biogroup of Yersinia ruckeri from diseased rainbow trout (Onchorhychus mykiss, Walbaum). Syst. Appl. Microbiol., 26, 127-131.

Bastardo, A., C. Ravelo and J. L. Romalde (2015): Phylogeography of Yersinia ruckeri reveals effects of past evolutionary events on the current strain distribution and explains variations in the global transmission of enteric redmouth (ERM) disease. Front. Microbiol., 6, 1198.

Bullock, G. L., H. M. Stuckey and E. B. Shotts, Jr (1978): Enteric redmouth bacterium: comparison of isolates from different geographic areas. J. Fish Dis., 1, 351-356.

Davies, R. L. (1990): O-serotyping of Yersinia ruckeri with spe- cial emphasis on European isolates. Vet. Microbiol., 22 299-307.

Davies, R. L. (1991): Virulence and serum-resistance in different clonal groups and serotypes of Yersinia ruckeri. Vet. Microbiol., 29, 289-297.

Davies, R. L. and G. N. Frerichs (1989): Morphological and biochemical differences among isolates of Yersinia ruckeri obtained from wide geographical areas. J. Fish Dis., 12, 357-365.

Eissa, A. E., M. Moustafa, M. Abdelaziz and N. A. Ezzeldeen (2008): Yersinia ruckeri infection in cultured Nile tilapia, Oreochromis niloticus, at a semi-intensive fish farm in lower Egypt. Afr. J. Aquat. Sci., 33, 283-286.

Ewing, W. H., A. J. Ross, Don J. Brenner and G. R. Fanning (1978): Yersinia ruckeri sp. Nov., the Redmouth (RM) Bacterium. Int. J. Syst. Bacteriol., 28, 37-44.

Fernandez, L., J. R. Lopez, P. Secades, A. Menendez, I. Marquez and J. A. Guijarro (2003): In vitro and in vivo studies of the Yrp1 protease from Yersinia ruckeri and its role in protective immunity against enteric red mouth disease of salmonids. Appl. Environ. Microbiol., 69, 7328-7335.

Fernández, L., P. Secades, J. R. Lopez, I. Márquez and J. A. Guijarro (2002): Isolation and analysis of a protease gene with an $A B C$ transport system in the fish pathogen Yersinia ruckeri: insertional mutagenesis and involvement in virulence. Microbiology, 148, 2233-2243.

Fernández, L., M. Prieto and J. A. Guijarro (2007): The iron- and temperature-regulated haemolysin $\mathrm{YhIA}$ is a virulence factor of Yersinia ruckeri. Microbiology, 153, 483-489.

Furones, M. D., C. J. Rodgers and C. B. Munn (1993): Yersnia ruckeri, the causal agent of enteric redmouth disease (ERM) in fish. Annual. Rev. Fish Dis., 3, 105-125.

Glenn, R. A., P. W. Taylor, E. H. Pelton, S. K. Gutenberger, M. A. Ahrens, L. M. Marchant and K. C. Hanson (2015): Genetic evidence of vertical transmission and cycling of Yersinia ruckeri in hatchery-origin fall Chinook salmon Oncorhynchus tshawytscha. J. Fish Wildlife Manag., 6, 44-54.

Haig, S. J., R. L. Davies, T. J. Welch, R. A. Reese and D. W. Verner-Jeffreys (2011): Comparative susceptibility of Atlantic salmon and rainbow trout to Yersinia ruckeri: relationship to $O$ antigen serotype and resistance to serum killing. Vet. Microbiol., 147, 155-161.

Kumer, G., S. Menanteau-Ledouble, M. Saleh and M. El-Matbouli (2015): Yersinia ruckeri, the causative agent of enteric redmouth disease in fish. Vet. Res., 46, 103.

Navais, R., J. Méndez, D. Pérez-Pascual, D. Cascales and J. A. Guijarro (2014): The yrpAB operon of Yersinia ruckeri encoding two putative U32 peptidases is involved in virulence and induced under microaerobic conditions. Virulence, 5, 619-624.

Ohtani, M., K. R. Villumsen, H. K. Strøm and M. K. Raida (2014) : 3D visualization of the initial Yersinia ruckeri infection route in rainbow trout (Oncorhynchus mykiss) by optical projection tomography. PLOS One, 9, e89672.

Romalde, J. L., B. MagariÑos, J. L. Barja and A. E. Toranzo (1993): Antigenic and molecular characterization of Yersinia ruckeri proposal for a new intraspecies classification. System. Appl. Microbiol., 16, 411-419.

Ross, A. J., R. R. Rucker and W. H. Ewing (1966): Description of a bacterium associated with redmouth disease of rainbow trout (Salmo gairdneri). Can. J. Microbiol., 12, 
$763-770$.

Rucker, R. R. (1966): Redmouth disease of rainbow trout (Salmo gairdneri). Bull. Off. Int. Epiz., 65, 5-6.

坂井貴光・大迫典久・飯田貴次 (2006) : レッドマウス病原因 菌の簡易迅速検出法について. 魚病研究, 41, 127-130.

Sakai, T., C. Nakayasu, T. Ito, S. Miwa, N. Oseko and T. Iida (2012): Virulence of Yersinia ruckeri for four indigenous fish species in Japan. Fish Pathol., 47, 74-79.

Secades, P. and J. A. Guijarro (1999): Purification and characterization of an extracellular protease from the fish pathogen Yersinia ruckeri and effect of culture conditions on production. Appl. Environ. Microbiol., 65, 3969-3975.

Shaow, L., W. Di, L. Hongbai and L. Tongyan (2013) : Isolation of Yersinia ruckeri strain $\mathrm{H} 01$ from farm-raised Amur Sturgeon Acipenser schrencki in China. J.Aquat. Anim. Health, 25, 9-14.

Strøm, H. K., M. Ohtani, B. Nowak, T. S. Boutrup, B. Jones and M. K. Raida (2018): Experimental infection by Yersinia ruckeri $\mathrm{O} 1$ biotype 2 induces brain lesions and neurological signs in rainbow trout (Oncorhynchus mykiss). J. Fish
Dis., 41, 529-537.

Tobback, E., A. Decostere, K. Hermans, F. Haesebrouck and K. Chiers (2007): Yersinia ruckeri infections in salmonid fish. J. Fish Dis., 30, 257-268.

Tobback, E., A. Decostere, K. Hermans, J. Ryckaert, L. Duchateau, F. Haesebrouck and K. Chiers (2009): Route of entry and tissue distribution of Yersinia ruckeri in experimentally infected rainbow trout Oncorhynchus mykiss. Dis. Aquat. Org., 84, 219-228.

Welch, T. J., D. W. Verner-Jeffreys, I. Dalsgaard, T. Wiklund, J. P. Evenhuis, J. A. G. Cabrera, J. M. Hinshaw, J. D. Drennan and S. E. LaPatra (2011): Independent emergence of Yersinia ruckeri biotype 2 in the United States and Europe. Appl. Environ. Microbiol., 77, 3493-3499.

Wrobel, A., J. C. Leo and D. Linke (2019): Overcoming Fish Defences: The Virulence Factors of Yersinia ruckeri. Genes (Basal), 10, 700.

Yamasaki, M., T. Sakai, T. Ito and K. Mori (2017): Bactericidal effects of disinfectants on Yersinia ruckeri. Fish Pathol., 52, 198-201. 